\title{
Pengaruh formulasi metil eugenol block plus terhadap tangkapan lalat buah Bactrocera spp. pada tanaman cabai
}

\author{
Formulation effect of methyl eugenol block plus to total catchment of \\ Bactrocera spp. on chili pepper
}

\author{
Agus Susanto $^{{ }^{*}}$, Agus Dana Permana ${ }^{2}$, Sri Hartati ${ }^{1}$, Tohidin, Desy Natalia Br. Saragih ${ }^{1}$ \\ ${ }^{1}$ Departement Hama dan Penyakit Tumbuhan, Fakultas Pertanian, Universitas Padjadjaran \\ Jalan Bandung-Sumedang KM. 21, Jatinangor, Sumedang 45363, Indonesia \\ ${ }^{2}$ Sekolah Ilmu dan Teknologi Hayati, Institut Teknologi Bandung \\ Jalan Ganesa No. 10 Bandung 40132, Indonesia
}

(diterima September 2020, disetujui Maret 2021)

\begin{abstract}
ABSTRAK
Lalat buah Bactrocera spp. merupakan salah satu hama penting pada tanaman cabai. Penggunaan metil eugenol (ME) block plus sebagai atraktan dalam perangkap merupakan salah satu cara pengendalian lalat buah. Percobaan bertujuan untuk mengetahui formulasi ME block plus yang tepat dalam meningkatkan tangkapan lalat buah pada lahan tanaman cabai. Percobaan dilaksanakan dari bulan Januari sampai April 2018 di Desa Lembang, Kecamatan Lembang, Kabupaten Bandung Barat. Percobaan menggunakan rancangan acak kelompok yang terdiri atas delapan perlakuan dan tiga ulangan. Perlakuan yang diuji, yaitu ME $2 \mathrm{ml}$ diaplikasikan di seluruh perlakuan pada kapas; block; esens cabai $4 \mathrm{ml}$ block; esens jambu $4 \mathrm{ml}$ block; esens jeruk $4 \mathrm{ml}$ block; esens belimbing $4 \mathrm{ml}$ block; esens mangga $4 \mathrm{ml}$ block; produk atraktan block berbahan aktif ME. Walaupun hasil penelitian menunjukkan bahwa seluruh perlakuan yang diuji tidak dapat menarik lalat buah betina, akan tetapi formulasi esens berhasil menarik lalat buah jantan sebesar $87 \%$. Esens cabai $4 \mathrm{ml}$ pada formulasi ME block $2 \mathrm{ml}$ merupakan perlakuan yang paling efektif meningkatkan tangkapan lalat buah jantan sebanyak 377 individu lalat buah/perangkap/minggu pada spesies Bactrocera dorsalis (Hendel), Bactrocera carambolae Drew \& Hancock, Bactrocera umbrosa Fabricius, dan lalat buah hibrida $B$. dorsalis x B. carambolae.
\end{abstract}

Kata kunci: Bactrocera, block kayu, cabai, esens buah, metil eugenol

\begin{abstract}
Fruit fly Bactrocera spp. is one of important pests in chili pepper. The use of methyl eugenol (ME) block plus as an attractant in traps is one method of controlling fruit flies populations. This study aims to find out the appropriate formulation of ME block plus formulation in increasing fruit fly catches on chili pepper. The experiment was carried out from January to April 2018 in Lembang Village, Lembang District, West Bandung Regency. The experiment used a randomized block design consists of eight treatments and three replications. The treatments tested were ME $2 \mathrm{ml}$ was applied to all treatments using cotton; block; chili essence $4 \mathrm{ml}$ block; $4 \mathrm{ml}$ block of guava essence; orange essence $4 \mathrm{ml}$ block; starfruit essence $4 \mathrm{ml}$ block; mango essence $4 \mathrm{ml}$ block; an attractant block product with the active ingredient ME. Although the results showed that all the treatments tested could not attract female fruit flies, the essence formulation was successful in attracting male fruit flies by $87 \%$. The $4 \mathrm{ml}$ chili essence in the $2 \mathrm{ml} \mathrm{ME}$ block formulation was the most effective treatment to increase male fruit fly catches by as much as 377 fruit flies/traps/week specifically the species Bactrocera dorsalis (Hendel), Bactrocera carambolae Drew \& Hancock, Bactrocera umbrosa Fabricius, and hybrid fruit flies B. dorsalis x B. carambolae.
\end{abstract}

Key words: Bactrocera, chili, fruit essence, methyl eugenol, wooden block

*Penulis korespondensi: Agus Susanto. Departement Hama dan Penyakit Tumbuhan, Fakultas Pertanian, Universitas Padjadjaran 


\section{PENDAHULUAN}

Lalat buah Bactrocera spp. merupakan salah satu hama penting yang menyerang pada tanaman cabai. Serangan lalat buah dapat menyebabkan penurunan kualitas dan kuantitas buah, bahkan pada serangan berat petani akan mengalami kerugian karena buah gagal untuk dipanen. Kerugian yang diakibatkan oleh serangan lalat buah dapat berkisar $20-60 \%$ dengan tingkat kerusakan yang terjadi ada pada rentang $5-100 \%$ pada berbagai jenis komoditas hortikultura (Hasyim 2014; Shinwari et al. 2015). Oleh karena itu, diperlukan pengendalian yang tepat untuk menekan kerugian akibat serangan lalat buah.

Penggunaan perangkap beratraktan menjadi salah satu pengendalian ramah lingkungan yang dapat digunakan untuk mengendalikan lalat buah. Atraktan dapat memikat lalat buah jantan masuk ke dalam perangkap dan berperan untuk memonitor populasi lalat buah serta mengganggu aktivitias kawin dari lalat buah (Hasyim et al. 2015). Meskipun metil eugenol (ME) bukan merupakan feromon, tetapi cara kerja dari ME hampir serupa dengan feromon, yaitu menarik imago lalat buah sehingga populasi lalat buah jantan menjadi berkurang yang menyebabkan frekuensi perkawinan menurun.

Menurut Kardinan et al. (2009) ME masih memiliki kelemahan, yaitu spesifik menarik lalat buah jantan saja. Adapun pengendalian alternatif untuk meningkatkan penggunaan perangkap ME, yaitu dengan penambahan aroma buah atau esens. Penambahan esens beraroma pada perangkap dapat meningkatkan kinerja senyawa ME untuk menarik lalat buah (Susanto et al. 2018a). Beberapa jenis lalat buah, seperti Drosophila suzukii Matsumura memiliki ketertarikan terhadap aroma buah, seperti rasberi dan blackberry serta meningkatkan ketertarikan lalat buah jantan serta betina (Huang \& Gut 2021). Kemudian berdasarkan hasil riset Cornelius et al. (2000), aroma mangga, jambu, jeruk, dan belimbing efektif untuk menarik lalat buah Bactrocera spp. di lapangan. ME block plus merupakan campuran antara ME dan esens buahbuahan dalam block kayu yang dapat menarik lalat buah jantan dan betina (Susanto et al. 2019).

Perangkap lalat buah dapat diformulasikan menggunakan block kayu. Perangkap untuk lalat buah menggunakan block dapat dibuat dengan menginjeksikan cairan ME pada block atau merendam block di dalam cairan ME. Formulasi ME block empat kali lebih efektif daripada ME yang diaplikasikan pada kapas karena tidak rentan terhadap cuaca, ekonomis, dan tidak perlu diganti ataupun diisi ulang (Sidahmed et al. 2014). Pengujian pengaruh formulasi ME block plus esens terhadap tangkapan lalat buah jantan dan betina belum pernah dilakukan. Percobaan perlu dilaksanakan untuk mengetahui pengaruh formulasi ME block plus yang dapat menarik lalat buah Bactrocera spp. jantan dan betina pada tanaman cabai.

\section{BAHAN DAN METODE}

\section{Tempat dan waktu percobaan}

Percobaan dilaksanakan di lahan cabai di Desa Lembang, Kecamatan Lembang, Kabupaten Bandung Barat yang berada pada ketinggian $>1.300 \mathrm{~m}$ dpl dengan luas lahan $2.000 \mathrm{~m}^{2}$. Identifikasi lalat buah dilakukan di Laboratorium Entomologi, Departemen Hama dan Penyakit Tumbuhan (HPT), Fakultas Pertanian, Universitas Padjadjaran. Percobaan berlangsung dari bulan Januari sampai April 2018.

\section{Penyiapan atraktan}

Percobaan ini menggunakan dua jenis atraktan. Atraktan pertama adalah ME yang tersedia di Laboratorium Hama Tanaman, Departemen HPT, Fakultas Pertanian, Universitas Padjadjaran. Atraktan kedua adalah esens buah yang merupakan bahan penambah aroma makanan komersial, berupa esens buah cabai, jambu, jeruk, belimbing, dan mangga.

\section{Pembuatan perangkap dan block kayu}

Perangkap dibuat menggunakan botol air mineral ukuran $600 \mathrm{ml}$ yang diberi 4 lubang sesuai arah mata angin menggunakan soldering iron sebagai jalan masuk lalat buah. Tutup botol diberi lubang kecil menggunakan soldering iron untuk memasukkan kawat sebagai media untuk menggantungkan kapas dan block kayu yang telah diberi perlakuan dan juga untuk menggantungkan perangkap di ajir tanaman. Block kayu direndam di dalam $2 \mathrm{ml}$ metil eugenol dan $4 \mathrm{ml}$ esens buah selama 24 jam (Singh et al. 2015). Block kayu 
yang digunakan berasal dari serutan kayu yang dipadatkan dengan ukuran $1 \mathrm{~cm}$ x $1 \mathrm{~cm}$ x $8 \mathrm{~cm}$ (Gambar 1).

Jenis kayu yang digunakan adalah particle board. Jenis kayu particle board dipilih karena dapat menyerap ME dan esens buah dengan baik saat uji coba. Kapas dan block kayu yang sudah diberi perlakuan kemudian dikaitkan pada ujung kawat yang berada di dalam botol. Sebelum dilakukan pemasangan, botol perangkap yang sudah siap kemudian diisi campuran $300 \mathrm{ml}$ air dan formalin dengan perbandingan $100: 1 \mathrm{ml}$ agar lalat buah yang tertangkap tidak membusuk dan dapat diidentifikasi. Model perangkap disajikan dalam Gambar 2.

\section{Pelaksanaan percobaan dan pengamatan}

Pemasangan perangkap dilakukan pada pertanaman cabai seluas $2.000 \mathrm{~m}^{2}$ umur tanaman 80 hari setelah tanaman (HST). Percobaan

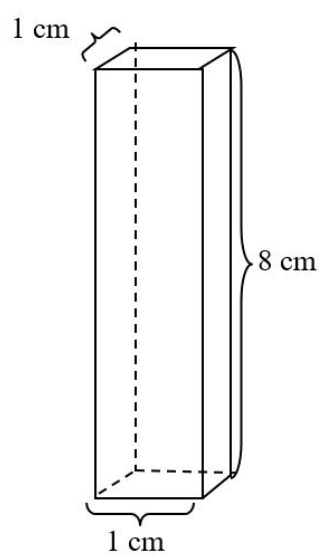

Gambar 1. Bentuk kayu untuk formulasi metil eugenol block.

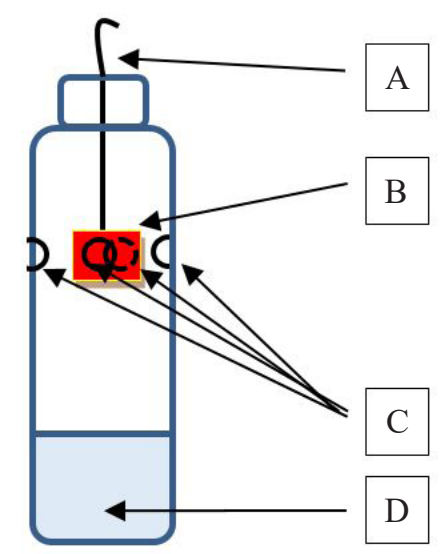

Gambar 2. Perangkap lalat buah. A: kawat pengait; B: metil eugenol block plus; C: empat buah lubang untuk jalan masuk lalat buah; D: air + formalin. dilaksanakan dengan metode eksperimen dan menggunakan rancangan acak kelompok (RAK) yang terdiri atas 8 perlakuan dan 3 ulangan. Perlakuan yang diuji, yaitu ME $2 \mathrm{ml}$ diaplikasikan di seluruh perlakuan pada kapas; block; esens cabai $4 \mathrm{ml}$ block; esens jambu $4 \mathrm{ml}$ block; esens jeruk $4 \mathrm{ml}$ block; esens belimbing $4 \mathrm{ml}$ block; esens mangga $4 \mathrm{ml}$ block; produk atraktan block berbahan aktif ME $2 \mathrm{ml}$. Jumlah perangkap yang dipasang, yaitu sebanyak 24 buah di seluruh sisi pertanaman cabai. Pemasangan perangkap dilakukan dengan cara menggantungkan botol perangkap pada ajir tanaman dengan ketinggian $170 \mathrm{~cm}$ dari atas tanah dan jarak antar perangkap sekitar 8 meter.

Pengamatan dilakukan setiap satu minggu sekali selama lima minggu dan dilakukan penghitungan jumlah lalat buah jantan dan betina yang tertangkap dari seluruh perangkap yang diganti setiap pengamatan. Identifikasi lalat buah dilakukan terhadap seribu individu lalat buah dari total tangkapan lalat buah selama lima minggu pengamatan yang diambil secara acak guna mengetahui spesies lalat buah yang menyerang. Identifikasi dilakukan menggunakan mikroskop tipe Z61. Selain itu, diamati data penunjang berupa faktor biotik dan abiotik untuk mengetahui pengaruhnya terhadap kepadatan populasi lalat buah dilapangan. Faktor biotik yang diamati setiap pengamatan, yaitu ketersediaan inang dengan mengambil buah dan faktor abiotik, yaitu curah hujan dan kelembapan. Skoring ketersediaan inang disajikan pada Tabel 1.

\section{Analisis data}

Analisis data hasil pengamatan dilakukan dengan menggunakan software SPSS 21.0. Data yang dianalisis meliputi pengaruh formulasi metil eugenol block plus terhadap tangkapan lalat buah.

Tabel 1. Skoring ketersediaan inang tanaman cabai pada lahan percobaan

\begin{tabular}{ll}
\hline Skoring & $\begin{array}{c}\text { Deskripsi ketersediaan inang } \\
\text { berdasarkan skor }\end{array}$ \\
\hline 1 & Inang dan buah tersedia $20 \%$ \\
2 & Inang dan buah tersedia $40 \%$ \\
3 & Inang dan buah tersedia $60 \%$ \\
4 & Inang dan buah tersedia $80 \%$ \\
5 & Inang dan buah tersedia $>80 \%$ \\
\hline
\end{tabular}


Pengujian signifikansi untuk mengetahui pengaruh rata-rata perlakuan menggunakan uji analysis of variance (ANOVA). Apabila terdapat pengaruh perlakuan maka dilakukan uji lanjut menggunakan uji jarak berganda Duncan pada taraf nyata $5 \%$. Data penunjang dianalisis dengan menggunakan analisis korelasi dan regresi.

\section{HASIL}

\section{Tangkapan lalat buah Bactrocera spp.}

Hasil percobaan menunjukkan bahwa tangkapan lalat buah Bactrocera spp. tertinggi dari seluruh perlakuan terdapat pada minggu pertama, yaitu sebanyak 2.569 individu, sedangkan tangkapan lalat buah terendah terdapat pada minggu keempat sebanyak 1.227 individu karena pada minggu tersebut buah cabai sudah dipanen (Tabel 2). Dari seluruh pengamatan tidak ditemukan adanya lalat buah betina yang terperangkap. Meskipun tidak ditemukan adanya lalat buah betina yang terperangkap, penambahan esens buah pada ME terbukti dapat meningkatkan tangkapan lalat buah jantan. Perlakuan dengan penambahan esens buah berbeda nyata dan memiliki tangkapan lalat buah jantan yang lebih tinggi dengan rata-rata $87 \%$ dibandingkan dengan perlakuan ME secara tunggal menggunakan kapas (A) dan block kayu (B) (Tabel 3).

Penambahan esens cabai pada ME block memiliki tangkapan lalat buah yang lebih banyak dibandingkan dengan perlakuan lainnya. Tangkapan lalat buah pada perlakuan penambahan esens cabai, yaitu sebanyak 1.885 individu. Sementara, pada perlakuan A dan B tangkapan lalat buah hanya sekitar 151 dan 398 individu. Selain itu, penambahan esens jeruk, belimbing, dan mangga memiliki tangkapan lalat buah yang lebih banyak dibandingkan dengan perlakuan produk atraktan block berbahan aktif ME (H).

\section{Keanekaragaman lalat buah yang diperoleh}

Karakter morfologi lalat buah dapat dilihat dari bagian sayap, toraks, maupun abdomennya. Berdasarkan identifikasi yang dilakukan, spesies lalat buah yang ditemukan di dalam perangkap didominasi oleh spesies Bactrocera dorsalis (Hendel) dengan persentase 95,5\%, diikuti oleh Bactrocera carambolae Drew \& Hancock 3,4\%,

Tabel 2. Tangkapan lalat buah pada lahan cabai dengan perlakuan ME block plus di Desa Lembang

\begin{tabular}{lcc}
\hline \multirow{2}{*}{ Pengamatan pada minggu ke - } & & Lalat buah yang tertangkap (individu) \\
\cline { 2 - 3 } & Jantan & Betina \\
\hline 1 & 2.569 & 0 \\
2 & 1.698 & 0 \\
3 & 1.360 & 0 \\
4 & 1.227 & 0 \\
5 & 1.274 & 0 \\
\hline
\end{tabular}

Tabel 3. Pengaruh penambahan esens buah terhadap tangkapan lalat buah jantan

\begin{tabular}{lcc}
\hline Perlakuan & $\begin{array}{c}\text { Tangkapan lalat buah } \\
\text { jantan }\end{array}$ & $\begin{array}{c}\text { Rata-rata tangkapan lalat } \\
\text { buah } \pm \text { SB }\end{array}$ \\
\hline A: ME $2 \mathrm{ml}$ (kapas) & 151 & $50,33 \mathrm{a} \pm 7,09$ \\
B: ME $2 \mathrm{ml}$ block & 398 & $132,66 \mathrm{a} \pm 25,42$ \\
C: ME $2 \mathrm{ml}+$ esens cabai $4 \mathrm{ml}$ block & 1.885 & $628,33 \mathrm{c} \pm 209,71$ \\
D: ME $2 \mathrm{ml}+$ esens jambu $4 \mathrm{ml}$ block & 1.032 & $344,00 \mathrm{~b} \pm 199,00$ \\
E: ME $2 \mathrm{ml}+$ esens jeruk $4 \mathrm{ml}$ block & 1.186 & $395,33 \mathrm{~b} \pm 141,80$ \\
F: ME $2 \mathrm{ml}+$ esens belimbing $4 \mathrm{ml}$ block & 1.057 & $352,33 \mathrm{~b} \pm 58,71$ \\
G: ME $2 \mathrm{ml}+$ esens mangga $4 \mathrm{ml}$ block & 1.376 & $458,66 \mathrm{~b} \pm 169,67$ \\
H: Produk atraktan block berbahan aktif ME & 1.043 & $347,66 \mathrm{~b} \pm 202,96$ \\
\hline
\end{tabular}

Angka yang ditandai dengan huruf yang sama pada kolom yang sama tidak berbeda nyata menurut uji jarak berganda Duncan pada taraf nyata 0,05 . 
Bactrocera umbrosa Fabricius 0,7\%, dan hibrida (B. dorsalis $\times$ B. carambolae) $0,4 \%$ (Tabel 4).

\section{Hubungan curah hujan dengan kelimpahan lalat buah}

Hasil analisis regresi menunjukkan bahwa faktor curah hujan tidak berpengaruh terhadap tangkapan lalat buah $\left(\mathrm{R}^{2}=0,144 ; \mathrm{P}=0,529\right)$. Terjadi kecenderungan pengurangan tangkapan lalat buah terhadap kenaikan curah hujan dilapangan begitu pula sebaliknya. Selain itu, pengaruh faktor curah hujan terhadap tangkapan lalat buah hanya sebesar $14,4 \%$. Penurunan tangkapan lalat buah yang diikuti dengan peningkatan curah hujan per minggu terjadi pada pengamatan minggu pertama sampai ketiga (Gambar 3). Curah hujan per minggu paling tinggi, yaitu 228,4 mm terjadi pada pengamatan minggu ketiga dengan tangkapan lalat buah tidak menunjukkan angka paling rendah. Tangkapan lalat buah paling rendah terdapat pada pengamatan minggu keempat, ketika curah hujan pada minggu keempat lebih rendah daripada minggu ketiga.

\section{Hubungan kelembapan dengan kelimpahan lalat buah}

Hasil analisis regresi menunjukkan bahwa faktor kelembapan memiliki korelasi yang positif dan tidak signifikan terhadap tangkapan lalat buah dilapangan $\left(\mathrm{R}^{2}=0,001 ; \mathrm{P}=0,982\right)$. Terjadi penurunan tangkapan lalat buah yang diikuti dengan peningkatan kelembapan per minggu pada pengamatan minggu pertama sampai ketiga (Gambar 4). Namun, pada pengamatan minggu ketiga sampai kelima mulai terjadi penurunan kelembapan perminggu yang diikuti dengan penurunan tangkapan lalat buah pada pengamatan minggu keempat dan peningkatan pada pengamatan minggu kelima.

\section{Hubungan pengaruh ketersediaan inang dengan kelimpahan lalat buah}

Hasil analisis regresi menunjukkan bahwa ketersediaan inang memberikan pengaruh nyata dan berkorelasi positif terhadap tangkapan lalat buah di lapangan $\left(\mathrm{R}^{2}=0,865 ; \mathrm{P}=0,05\right)$. Hal ini menunjukkan bahwa terjadi peningkatan tangkapan lalat buah terhadap peningkatan ketersediaan inang begitu pula sebaliknya (Gambar 5). Selain itu, persentase pengaruh ketersediaan inang terhadap tangkapan lalat buah sebesar $86,5 \%$ dan nilai signifikasi sebesar $0,022(\mathrm{P}<0,05)$. Hasil pengamatan menunjukkan bahwa pada pengamatan minggu pertama memiliki tangkapan lalat buah tertinggi. Pengamatan minggu pertama

Tabel 4. Hasil identifikasi lalat buah yang terperangkap dalam formulasi ME block plus

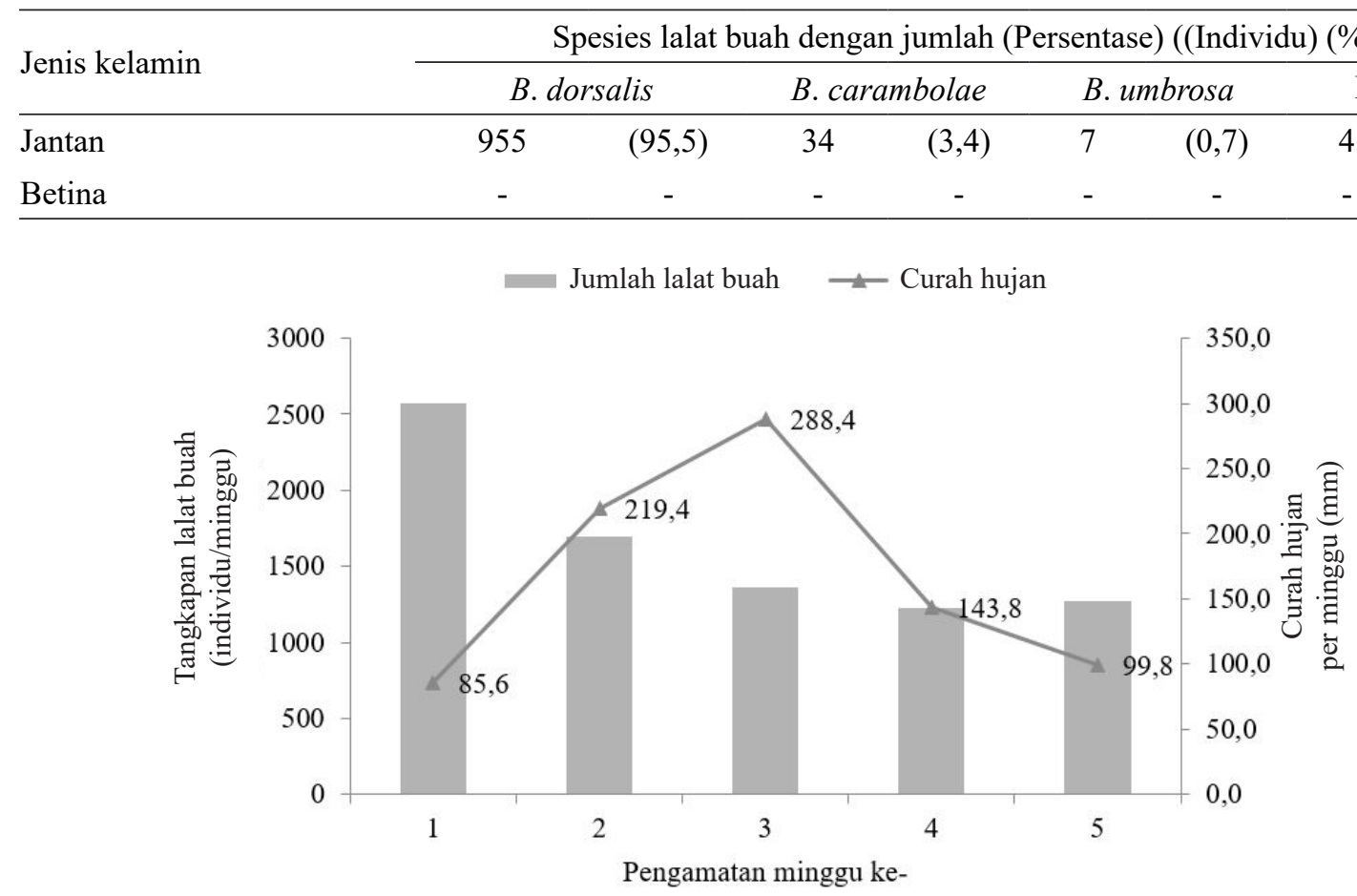

Gambar 3. Hubungan curah hujan dan tangkapan lalat buah. 


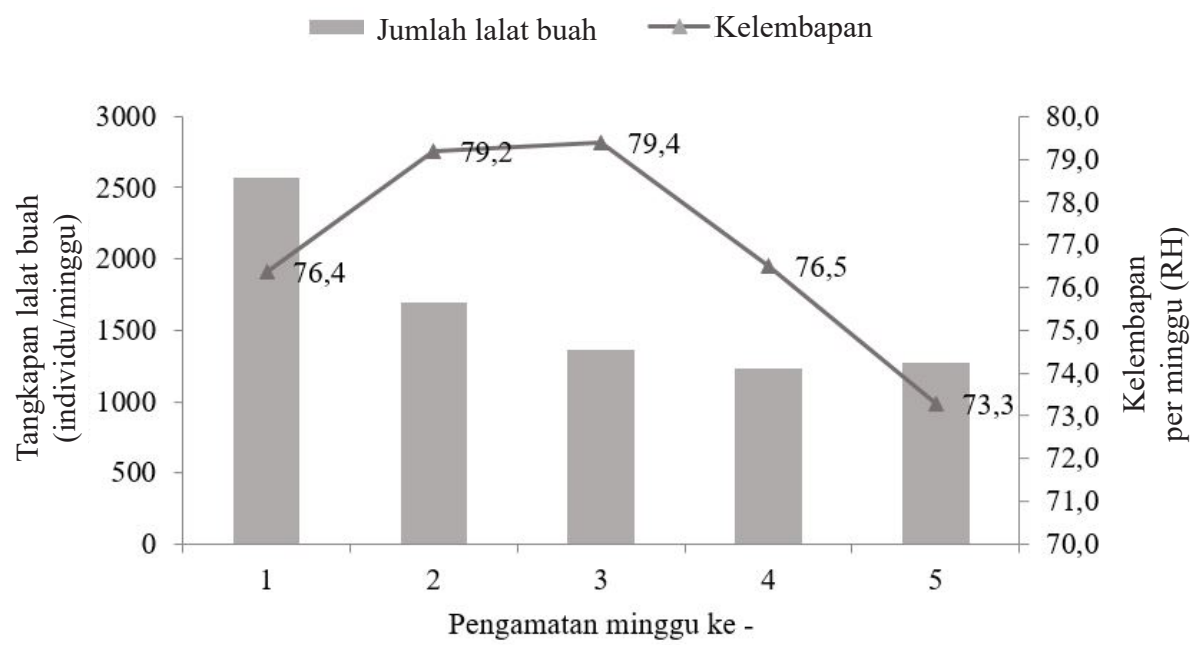

Gambar 4. Hubungan kelembapan dan tangkapan lalat buah.

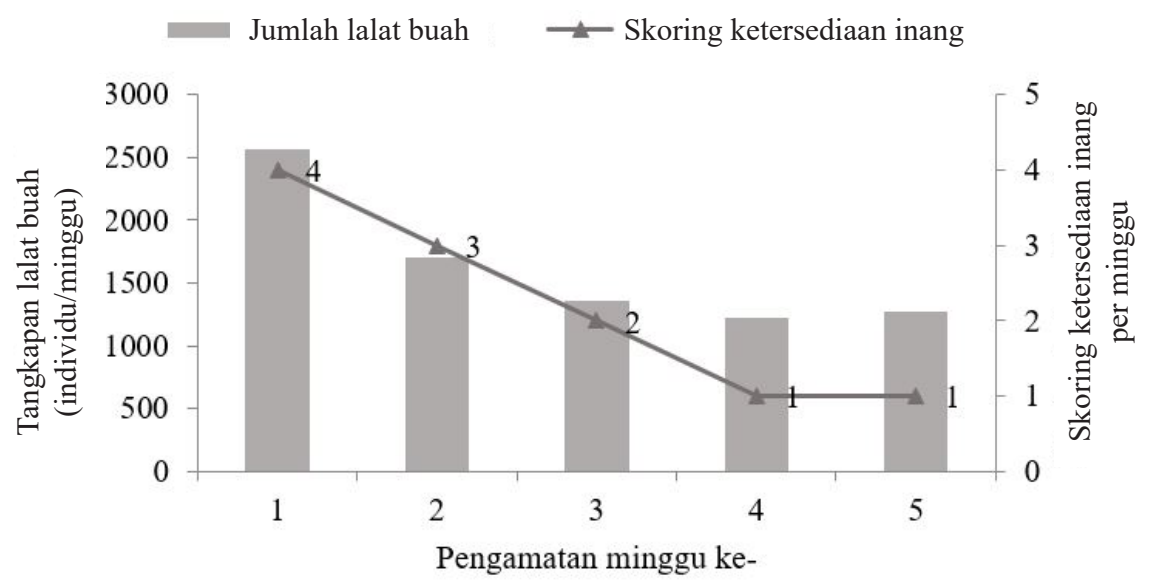

Gambar 5. Hubungan ketersediaan tanaman inang dan tangkapan lalat buah.

dilakukan saat cabai berumur 112 HST, dengan ketersediaan inang memiliki persentase sebesar $80 \%$. Namun, pada pengamatan minggu kedua mulai terjadi penurunan tangkapan lalat buah yang terus berlanjut sampai pengamatan minggu kelima.

\section{PEMBAHASAN}

Penambahan esens pada formulasi ME block plus diamati dan dianalisis untuk mengetahui keefektifan perangkap dalam menarik lalat buah jantan dan betina di lapangan. Hasil percobaan menunjukkan bahwa dari seluruh pengamatan hanya lalat buah jantan saja yang terperangkap, sedangkan lalat buah betina tidak terperangkap. Konsentrasi esens buah yang digunakan dalam percobaan yang telah dilakukan diduga belum cukup untuk menarik minat buah betina. Selain itu, faktor lain yang memungkinkan bahwa terdapat perbedaan genetik yang signifikan sehingga memengaruhi preferensi lalat buah di berbagai wilayah. Walaupun tidak menarik lalat buah betina, penambahan esens buah pada perangkap ME block terbukti meningkatkan tangkapan lalat buah jantan.

Perlakuan penambahan esens buah pada ME menunjukkan pengaruh dalam meningkatkan tangkapan lalat buah jantan. Hal tersebut diduga karena esens yang digunakan sesuai dengan aroma buah dari tanaman inang Bactrocera spp. Kardinan (2007) menyatakan bahwa penambahan esens dapat meningkatkan hasil tangkapan lalat buah jantan hingga $80 \%$. Berdasarkan hasil penelitian Manoi (2016) tingginya tangkapan lalat buah jantan pada perangkap ME dapat menyebabkan penekanan atau memotong populasi lalat buah jantan di lapangan yang secara signifikan akan memberi pengaruh negatif terhadap regenerasi populasi lalat buah berikutnya.

Perlakuan dengan penambahan esens cabai pada ME block memiliki tangkapan lalat buah tertinggi. Hal tersebut diduga dapat disebabkan 
oleh kebiasaan Bactrocera spp. untuk mencari inang sesuai dengan tanaman di lahan. Hasil penelitian didukung oleh studi Susanto et al. (2018b) bahwa perlakuan ME dengan penambahan esens mangga yang diaplikasikan di pertanaman mangga memiliki jumlah tangkapan yang paling tinggi dibandingkan dengan penambahan esens belimbing, jeruk, dan jambu. Menurut Koswanudin et al. (2018) tanaman buah yang jumlahnya lebih banyak atau padat di suatu lokasi tertentu secara alami akan lebih mungkin dikunjungi oleh lalat buah, sedangkan tanaman buah yang jarang terwakili di suatu daerah mungkin jarang di jumpai oleh lalat buah. Karakteristik fisik dan komposisi kimiawi dapat memengaruhi preferensi serangga terhadap tanaman tertentu sebagai inang (Kostal 1993). Liu \& Zhou (2015) menyatakan bahwa bau tanaman inang memiliki peran kunci terhadap pencarian tanaman inang oleh lalat buah. Hal tersebut juga menjadi salah satu faktor rendahnya tangkapan lalat buah pada perlakuan A dan B.

Lalat buah pada lokasi percobaan didominasi oleh spesies $B$. dorsalis dengan persentase $95,5 \%$. Hal ini berkaitan dengan penelitian Susanto et al. (2017) bahwa dari seluruh lalat buah yang terperangkap dalam perangkap percobaan pada pertanaman cabai, populasi $B$. dorsalis mencapai 93\%, diikuti B. carambolae sebesar 7\%. Hasil penelitian Saputra et al. (2019) menunjukkan bahwa presentase tangkapan lalat buah $B$. dorsalis pada pertanaman cabai berkisar 45,18-81,71\%, dengan rata-rata $60,15 \%$ dari total lalat buah yang terperangkap. Tangkapan lalat buah $B$. dorsalis yang tinggi disebabkan oleh spesies tersebut bersifat polifag, mempunyai daya reproduksi yang tinggi, penyebaran luas, dan memiliki kemampuan jelajah yang tinggi (Vargas et al. 2007; Vargas et al. 2015).

Pada umumnya populasi lalat buah yang tinggi menyebabkan intensitas serangan yang tinggi. Menurut Appiah et al. (2009), faktor abiotik dapat memengaruhi perkembangan populasi lalat buah dilapangan. Pada percobaan ini, faktor abiotik berupa curah hujan dan kelembapan tidak berpengaruh terhadap tangkapan lalat buah di pertanaman cabai. Hasil penelitian Boopathi et al. (2013) melaporkan bahwa faktor iklim berupa curah hujan dan hari hujan tidak berpengaruh terhadap populasi lalat buah di pertanaman cabai. Sementara, tidak adanya pengaruh faktor kelembapan terhadap tangkapan lalat buah dapat disebabkan oleh area percobaan cenderung memiliki kelembapan yang optimal bagi lalat buah. Menurut Isnaini (2013), kelembapan optimum untuk perkembangan lalat buah adalah $62-90 \%$. Selama percobaan berlangsung, kelembapan berada pada angka sekitar 73-80\%. Hal tersebut menunjukkan bahwa selama percobaan berlangsung, kelembapan selalu berada pada tingkat optimum. Tidak berpengaruhnya curah hujan dan kelembapan pada pertanaman cabai dapat disebabkan pula oleh ketersediaan inang, pada pengamatan minggu pertama ketersediaan inang dilapangan masih tinggi dengan skor 4 (80\%). Menurut Peng et al. (2006) ketersediaan tanaman inang merupakan salah satu faktor penentu fluktuasi populasi lalat buah.

Ketersediaan inang berkaitan dengan tangkapan lalat buah. Gambar 5 menunjukkan adanya peningkatan dan penurunan tangkapan lalat buah pada setiap minggunya. Pola peningkatan dan penurunan tangkapan lalat buah tersebut berkaitan dengan ketersediaan buah di lapangan. Tingginya tangkapan lalat buah pada minggu pertama karena kondisi buah cabai memasuki fase pematangan. Menurut Israely et al. (1997) populasi lalat buah bertambah dengan cepat jika tanaman inang menghasilkan buah pada kondisi matang (mature).

Semakin banyak ketersediaan inang cabai di lahan maka semakin besar kemungkinan meningkatnya populasi lalat buah pada tanaman tersebut. Sementara itu, terjadinya penurunan pada minggu selanjutnya karena mulai dilakukan pemanenan pada buah yang sudah matang sehingga ketersediaan inang dilapangan terus menurun setiap minggunya. Susanto (2017) mengemukakan bahwa dampak yang terjadi akibat pemanenan buah cabai merah memengaruhi penurunan jumlah populasi lalat buah dilahan karena sumber inang tempat meletakkan telur telah berkurang dan akan kembali meningkat lagi seiring dengan pematangan buah berikutnya. Hal ini menunjukkan bahwa ketersediaan tanaman inang berpengaruh terhadap tangkapan lalat buah dan merupakan salah satu faktor penentu fluktuasi populasi lalat buah. 


\section{KESIMPULAN}

Formulasi ME block plus efektif dalam memerangkap lalat buah Bactrocera spp. jantan pada tanaman cabai. Perlakuan dengan penambahan esens cabai $4 \mathrm{ml}$ pada formulasi ME block $2 \mathrm{ml}$ merupakan perlakuan paling efektif dalam meningkatkan tangkapan lalat buah jantan, tetapi belum efektif dalam menarik lalat buah betina. Faktor biotik berupa ketersediaan inang sangat berpengaruh terhadap jumlah tangkapan lalat buah, sedangkan faktor iklim berupa suhu, curah hujan, dan curah hujan tidak berpengaruh.

\section{UCAPAN TERIMA KASIH}

Penelitian ini didanai DIKTI melaui SKIM Penelitian Unggulan Strategis Nasional Tahun I, dengan SK No. 04/UN6.E/LT/2018, tanggal 6 Februari 2018.

\section{DAFTAR PUSTAKA}

Appiah EF, Nuamah KA, Ofori DO. 2009. Abudance and distribution of the Mediterranean fruit fly Ceratitis capitate (Diptera: Tephritidae), in Late Valencia citrus orchards in Ghana. International Journal of Tropical Insect Science 29:11-16. doi: https://doi.org/10.1017/S1742758409351036.

Boopathi T, Singh SB, Ngachan SV, Manju T, Ramakrishna Y, Lalhruaipuii. 2013. Influence of weather factors on the incidence of fruit flies in chilli (Capsicum annuиm L.) and their prediction model. Pest Management in Horticultural Ecosystems 19:194-198.

Cornelius ML, Duan JJ, Messing RH. 2000. Volatile fruit flies odors as attractants for the oriental fruit fly (Diptera: Tephritidae). Journal of Economic Entomology 93:93-100. doi: https:// doi.org/10.1603/0022-0493-93.1.93.

Hasyim A. 2014. Teknologi pengendalian hama lalat buah pada tanaman cabai. Jurnal Iptek Hortikultura 10:20-25.

Hasyim A. Setiawati W, Lukman L. 2015. Inovasi teknologi pengendalian OPT ramah lingkungan pada cabai: upaya alternatif menuju ekosistem harmonis. Pengembangan Inovasi Pertanian $8: 1-10$

Huang J, Gut LJ. 2021. Impact of background fruit odors on attraction of Drosophila suzukii
(Diptera: Drosophilidae) to its symbiotic yeast. Journal of Insect Science 21:4. doi: https:// doi.org/10.1093/jisesa/ieab016.

IsnainiYN. 2013. Identifikasi Spesies dan Kelimpahan Lalat Buah Bactrocera spp. di Kabupaten Demak. Skripsi. Semarang: Universitas Negeri Semarang.

Israely N, Yuval B, Kitron U, Nestel D. 1997. Population fluctuations of adult mediterranean fruit flies (Diptera: Tephritidae) in a mediterranean heterogenous agricultural region. Journal of Environmental Entomology 26:12631269. doi: https://doi.org/10.1093/ee/26.6.1263.

Kardinan A. 2007. Pengaruh campuran beberapa jenis minyak nabati terhadap daya tangkap lalat buah. Buletin Penelitian Tanaman Rempah dan Obat 18:60-66. doi: https://doi.org/10.21082/ jlittri.v15n3.2009.101-109.

Kardinan A, Bintoro MH, Syakir M, Amin AA. 2009. Penggunaan selasih dalam pengendalian hama lalat buah pada mangga. Jurnal Littri 15:101-109.

Kostal V. 1993. Physical and chemical factors influencing landing andoviposition by the cabbage root fly on host-plant models. Entomologia Experimentalis et Applicata 66:109-118. doi: https://doi.org/10.1111/j.1570-7458.1993. tb00698.x.

Koswanudin D, Basukriadu A, Samudra IM, Ubaidillah R. 2018. Host preference fruit flies Bactrocera carambolae (Drew \& Hancock) and Bactrocera dorsalis (Drew and Hancock) (Diptera: Tephritidae). Jurnal Entomologi Indonesia 15:40-49. doi: https://doi.org/10.5994/ jei.15.1.40.

Liu L, Zhou Q. 2015. Olfactory response of female Bactrocera minax to chemical components of the preference host citrus volatine oils. Journal of Asia-Pacific Entomology 13:637-642. doi: https://doi.org/10.1016/j.aspen.2016.05.008.

Manoi E, Rimbing J, Memah V. 2016. Jenis dan populasi lalat buah (Bactrocera sp.) pada tanaman cabai keriting (Capsicum annuum L.) di Kota Tomohon. Cocos 7:1-12.

Peng C, Hui Y, Jianhong L. 2006. Population dynamics of Bactrocera dorsalis (Diptera: Tephritidae) and analysis of the factors influencing the population in Ruili, Yunnan Province, China. Acta Ecologica Sinica 26:2801-2808. doi: https://doi. org/10.1016/S1872-2032(06)60044-9.

Saputra HM, Sarinah, Hasanah M. 2019. Kelimpahan dan dominansi lalat buah (Diptera: Tephritidae) pada pertanaman cabai (Capsicum annuum L.), di Desa Paya Benua, Bangka. Agrosainstek 3:36- 
41. doi: https://doi.org/10.33019/agrosainstek. v3i1.38.

Shinwari I, Khan S, Khan MA, Ahmad S, Shah SF, Mashwani MA, Khan MA. 2015. Evaluation of artificial larval diets for rearing of fruit fly Bactrocera zonata (Diptera: Tephritidae) under laboratory condition. Journal of Entomology and Zoology Studies 3:189-193.

Sidahmed OAA, Taha AK, Hassan GA, Abdalla IF. 2014. Evaluation of pheromone dispenser units in methyl eugenol trap against Bactrocera invadens (Drew, Tsuruta, and White) (Diptera: Tephritidae) in Sudan. Sky Journal of Agricultural Research 3:148-151.

Singh M, Gupta D, Gupta PR. 2015. Evaluation of wooden block lure traps for mass trapping of fruit flies, Bactrocera spp. in mango orchards. International Journal of Farm Sciences 5:236240.

Susanto A, Supriyadi Y, Tohidin, Susniahti N, Hafizh V. 2017. Fluktuasi populasi lalat buah Bactrocera spp. (Diptera: Tephritidae) pada pertanaman cabai merah (Capsicum Annuum) di Kabupaten Bandung, Jawa Barat. Jurnal Agrikultura 28:141-150. doi: https://doi.org/10.24198/ agrikultura.v28i3.15747.

Susanto A, Luciana D, Aprianti SR. 2018a. Addition of mango essence to methyl eugenol more attracted to Bactrocera dorsalis Complex (Diptera: Tephritidae) on mango plantation in Majalengka, West Java. Research Journal of Chemistry and Environment 22:274-279.
Susanto A, Natawigena WD, Lindung TP, Neng INA. 2018b. The effect of addition of several fruit essences on methyl eugenol trap in attracting fruit flies Bactrocera dorsalis complex at Pasirmuncang Village, Majalengka. Jurnal Perlindungan Tanaman Indonesia 22:150-159. doi: https://doi.org/10.22146/jpti.27001.

Susanto A, Nasahi C, Rumaisha YK, Murdita W, dan Lestari TMP. 2019. Penambahan essens buah terhadap keefektifan metil eugenol dalam menarik Bactrocera spp. Drew \& Hancock. Jurnal Agrikultura 30:53-62. doi: https://doi. org/10.24198/agrikultura.v30i2.23315.

Vargas RI, Mau RL, Jang EB. 2007. The hawaii fruit fly area-wide pest management program: accomplishments and future directions. Proceedings of the Hawaiian Entomological Society 39:99-104.

Vargas RI, Piñero CJ, Leblanc L. 2015. An overview of pest species of Bactrocera fruit flies (Diptera: Tephritidae) and the integration of biopesticides with other biological approaches for their management with a focus on the Pacific Region. Insects 6:297-318. doi: https://doi.org/10.3390/ insects6020297. 